
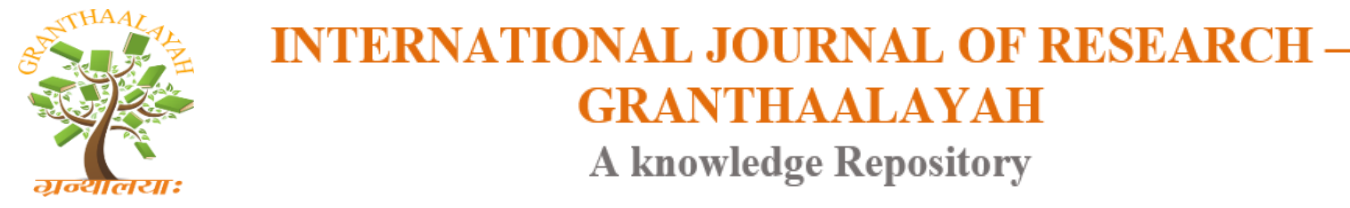

Science

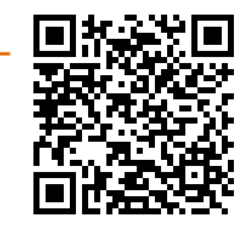

\title{
AYURVEDIC MANAGEMENT OF VATA-KAFAJ KUSHTA W.S.R. CONTACT ALLERGIC DERMATITIS- A CASE STUDY
}

\author{
Dnyaneshwar.K.Jadhav ${ }^{* 1}$, Dr Shilpa Prakash Yerme ${ }^{2}$, Dr Smita Zambare ${ }^{3}$ \\ ${ }^{* 1}$ M.D. (Ayurved)., D.P.K., D.A.Y., D.M.T., EMSO., C.PSY., C.S.D, Assistant Professor, \\ Kaychikitsa Department, Shri Dhanwantri Ayurvedic Medical College \& Research Centre, \\ Mathura-281401, India \\ ${ }^{2}$ MD Kriya Sharir, Professor \& HOD, Kriyasharir Department, S.G.R. Ayurved College \\ Solapur, India \\ ${ }^{3}$ MD (Ayurved)., MA Sanskrit, PGDHM, Assistant Professor, Swasthvritta Department, Shri \\ Dhanwantri Ayurvedic Medical College \& Research Centre, Mathura- 281401, India
}

\begin{abstract}
In Ayurveda, all skin diseases have been described under the term of kushtha. All skin diseases come under kushtha but all kushtha not come under skin diseases.

kushtha classified into Maha-kushtha and Kshudra Kushtha. Acharyas have described that all kushtha have Tridoshic involvement but the type of kushtha depends on the predominance of particular doshas. Contact allergic dermatitis (CAD) is an occupational disease.it is hypersensitivity reaction to plethora of antigen in the environments.

The present case study is successful Ayurvedic management of a case of vata-kaphaj kushata. A 48 year old female patient came to us with chief compliant of ubhay hasat twakvaivrya, kandu since 1 month. She get relief within 7 days. Ayurvedic management involving sukshma trifala, gandharva haritaki, stanik snehan followed by Awagaha.
\end{abstract}

Keywords: Vata-Kafaj Kushta; Contact Allergic Dermatitis; Ayurvedic Management.

Cite This Article: Dnyaneshwar.K.Jadhav, Dr Shilpa Prakash Yerme, and Dr Smita Zambare. (2017). "AYURVEDIC MANAGEMENT OF VATA-KAFAJ KUSHTA W.S.R. CONTACT ALLERGIC DERMATITIS- A CASE STUDY." International Journal of Research Granthaalayah, 5(7), 429-435. https://doi.org/10.29121/granthaalayah.v5.i7.2017.2150.

\section{Introduction}

kushta is group of skin disorders. All skin diseases come under kushtha but all kushtha not come under skin diseases. Vitiated doshas cause abnormal colour of skin and produced degeneration of skin, this condition called as kushta twakvaivrya (discoloration), kandu (itcing), strav(bleeding), puy uttpati (pus formation) are common symptoms found in the kushta. ${ }^{[1]}$ Kushtha is produced invariably by the vitiation of the seven factors i.e. 3 Doshas and 4 Dushyas ${ }^{[2]}$.Acharyas have described that all kushtha have Tridoshic involvement but the type of kushtha depends on the 
predominance of particular doshas. Changing life style invited many life style disease. Changing life style like eating ice cream at night, consumption of undigested \& heavy food, unhealthy diet, stress enhance the cases of kushta.

Contact allergic dermatitis is common in occupations that involve repeated hand washing or repeated exposure of the skin to water, food materials, and other irritants. High-risk occupations include cleaning, hospital care, food preparation, and hairdressing. ${ }^{[3]}$ The hands are the most important sites of contact allergic dermatitis. Repeated workplace exposure of the hands to soaps, cleansers, and solvents is the source of most occupational skin disorders.

Most cases found on contact dermatitis concern allergic contact dermatitis. Almost any material may be cause cutaneous allergic, if the exposure is sufficiently prolonged and/or the concentration of the substance sufficiently high. Environmental factors may enhance the effect of other irritants.

Contact allergic dermatitis affects women almost twice as often as men, Due to greater role in housecleaning and the care of small children at home. The definitive treatment of Contact allergic dermatitis is the identification and removal of any potential causal agents.

\subsection{A case report as follow}

A 48 year old Female patient came to us with chief compliant of -

1) ubhay hasat twakvaivrya

2) kandu

Patient had above complaints since 1 month.

\subsection{History of personal illness}

The patient was normal 1 month back. Since then patient have been suffering from ubhay hasat twakvaivrya, kandu. For this patient took treatment from different Allopathy doctors but got no relief, then he came to our opd for Ayurvedic treatment.

\subsection{Personal History}

Occupation: House wife (before 2 year ago she had house cleaning work as job).

$\mathrm{O} / \mathrm{E}$ :

Nadi $($ pulse $)=64 / \mathrm{min}$.

Mala $($ stool $)=$ MalaVibandha

Mutra $($ urine $)=$ Normal.

Jeeva $($ tounge $)=$ Eshatha saam .

Agni $=$ Kshudhamandya.

Shabda $($ speech $)=$ Normal.

Sparsha $($ skin $)=$ Khar, twakvaivrya .

Druka (eyes) = Drushtimandya.

Akruti = Madhyama. 
Bala $=$ Madhyama .

Raktadaaba $($ B.P $)=100 / 70 \mathrm{~mm} / \mathrm{Hg}$.

\section{Material \& Methods}

\subsection{Material}

\begin{tabular}{|l|l|l|l|l|}
\hline \multicolumn{4}{|l|}{ INTERNAL MEDICINE } \\
\hline SR.NO & DRUG & DOSE & DURATION & ANUPAN \\
\hline $\mathbf{1}$ & Sukshma trifala & $250 \mathrm{mg}$ & $1 \mathrm{BD}$ & Luck warm water \\
\hline $\mathbf{2}$ & gandharva haritaki & $500 \mathrm{mg}$ & $2 \mathrm{HS}$ & Luck warm water \\
\hline
\end{tabular}

\begin{tabular}{|c|c|c|}
\hline \multicolumn{3}{|l|}{ PANCHAKRMA } \\
\hline KARMA & DRUG & DURATION \\
\hline $\begin{array}{l}\text { Stanik snehan (hastanguli } \\
\text { pradeshi) }\end{array}$ & Karanja tail + nimba tail & $\begin{array}{l}\text { With Koshana tail for } 10 \\
\text { min }\end{array}$ \\
\hline Avagahana & $\begin{array}{l}\text { Choorna of }(\text { Trifala }+ \text { khadir } \\
+ \text { nimba })\end{array}$ & For $15-20 \mathrm{~min}$ \\
\hline Local application of Cream & Pentaphye p5 cream. & twice in days \\
\hline
\end{tabular}

\subsection{Methods}

- Centre of study: Nakshatra Ayurved clinic \& Research canter.

- Type of study: Simple random single case study.

\section{Discussion}

\subsection{Discussion on vhyadhi}

Hetu of vata-kaphaj kushata as ${ }^{(4)}$ -

1) Ahar:

- Improper and irregular diet causes the disturbance of vatadosha.

- Abhishandi food product like Dadhi in daily diet.

- Grains: Navadhanyak. (Daily plenty of rice in diet)

2) Vihar:

- Working in water with different types of soap \& detergent powder.

- Suppression of natural urge (Mala-muta vega dharan).

- Diwaswap.

3) Manasika nidan- Chinta and vegavrodha causes vata vrudhi.

\begin{tabular}{|l|l|l|}
\hline \multicolumn{2}{|l|}{ SANPRAPTI GHATAK: } \\
\hline Dosh & Vata & Sheet, Ruksha, khar - guna vrudhi \\
\hline & Kafa & Sheet, guru - guna vrudhi. \\
\hline Dushya & Rasa, Rakta. & \\
\hline Adhishtana & Twaka & \\
\hline
\end{tabular}




\begin{tabular}{|c|c|c|}
\hline \multicolumn{3}{|c|}{ SANPRAPTI } \\
\hline & Hetu sevan & \\
\hline Rakta dushti & 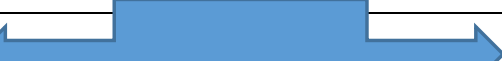 & Vata-kafa prakop \\
\hline & $\begin{array}{l}\text { Jala sampark (prolonge } \\
\text { work in water) }\end{array}$ & \\
\hline & 5 & \\
\hline & $\begin{array}{l}\text { sheet guna of Jala cause } \\
\text { Vata-kafa prakop }\end{array}$ & \\
\hline & hastapradeshi khavaigunya & \\
\hline & 5 & \\
\hline & $\begin{array}{l}\text { hastapradeshi prakrupit } \\
\text { Dosha stansanshrya }\end{array}$ & \\
\hline & 4 & \\
\hline & $\begin{array}{l}\text { ubhay hasat twakvaivrya, } \\
\text { kandu }\end{array}$ & \\
\hline & 5 & \\
\hline & vata-kaphaj kushata & \\
\hline
\end{tabular}

\section{Causes of Contact allergic dermatitis (CAD) as -}

Common causes of Contact allergic dermatitis (CAD) are Dry air and temperature variation, Solvents, water, Metalworking fluids, Micro trauma, Mechanical trauma, Rubber gloves, Sodium lauryl sulphate, Hydrofluoric acid, Alkalis. In this case study main cause of disease are water \& solvents.

\section{Pathophysiology of Contact allergic dermatitis (CAD) as ${ }^{(5)}$ -}

Contact allergic dermatitis (CAD) is the clinical result of sufficient inflammation arising from the release of pro-inflammatory cytokines from skin cells (principally keratinocytes), usually in response to chemical stimuli. Different clinical forms may arise. The three main pathophysiological changes are skin barrier disruption, epidermal cellular changes, and cytokine release.

Solvents cause cutaneous irritation because they remove essential fats and oils from the skin, which increases trans-epidermal water loss and renders the skin susceptible to the increased direct toxic effects of other previously well-tolerated cutaneous exposures. The alcohol propanol is less irritating to the skin than the detergent sodium lauryl sulphate.

$\mathrm{p} \mathrm{Ka}$, an acid dissociation constant, is a quantitative measure of the strength of an acid in solution. $\mathrm{p} \mathrm{K}$ a has been shown to be highly predictive of acute skin irritation for acids and bases: acids with a $\mathrm{p} \mathrm{K}$ a of less than 4 and bases with a $\mathrm{p}$ Ka of less than 8 are highly irritative. 


\subsection{Discussion on Medicine (Sampraptibhnga)}

- Sukshma trifala: it consist of medicinal plant namely terminalia chebula, terminalia beleria and emblica officinalis with that small quantity of kajjali.it has been used extensively as drug against number of diseases ${ }^{(6)}$. Trifala strengthen the different tissue of body. Prevent ageing, promotes health and immunity. Kajjali is yogavahi and it claimed to improve the activity of trifala. its correct constipation, cleanses and detoxifies the whole body. Improve digestion ${ }^{(7)}$. Ultimately its removes aam from body which is root of most of skin disease.it exhibits anti-viral, anti-bacterial, anti-fungal, anti-allergic properties. ${ }^{(8)}$.trifala show immunomodulatory properties and helps in improving the body's defence system ${ }^{(9)}$

- Gandharva haritaki ${ }^{(\mathbf{1 0})}$ : Gandharva haritaki is polyherbal ayurvedic medicine.Its contains erand tail,bal haritaki,sunthi,sandhav and savarchal lawana.it has purgative and laxative action. Gandharva haritaki evacuates bowel and removes toxins from body.Main cause of this disease is vata-kafa prakop \& raktadushti.rakat dusthi present in this disease. Rakat-pitta have closed relation. virechana is best treatment for pitta. There are two types of virechan as ruksha \& sasneha.as there is vataprakop so Gandharva haritaki is given as sasneha virechan.

- Stanik snehan: Stanik snehan is done with mixture of Karanja tail ${ }^{(\mathbf{1 1})} \&$ nimba tail $^{(\mathbf{1 2})}$. Mixture of this two tail taken as warm \& applied on both hand \& kept for 15 min. Its act as Vata shaman, kandughna, Decreases dryness.

- Avagahana: In avagahana we use triphala, khadir, nimba kwatha which is kandughna, tridoshaghna, vranya, raktashodhaka. ${ }^{(13)}$ This procedure brings sweat on the skin through hair follicle by opening the pores of the skin. Due to Avagahana agni is incesses \& the fatty tissue get mobilised. While throwing out waste as Ama (toxin) through the skin it also helps liquefy aggravated doshas, dilating all body channels for cleaning.

- For Local application pentaphyte 55 cream is advised. Which contains panchwalkal. This help for heeling skin.

\section{Observations and Result}

\begin{tabular}{|l|l|l|}
\hline \multirow{2}{*}{ Twakvaivrya } & 18.2 .2017 & 25.2 .2017 \\
\cline { 2 - 3 } & $+\boldsymbol{2}$ & $\mathbf{0}$ \\
\hline \multirow{2}{*}{ Kandu } & 18.2 .2017 & 25.2 .2017 \\
\cline { 2 - 3 } & +++ & $\mathbf{0}$ \\
\hline
\end{tabular}

Clinical examination of the patients revealed regression of symptom due to our Ayurvedic management. 

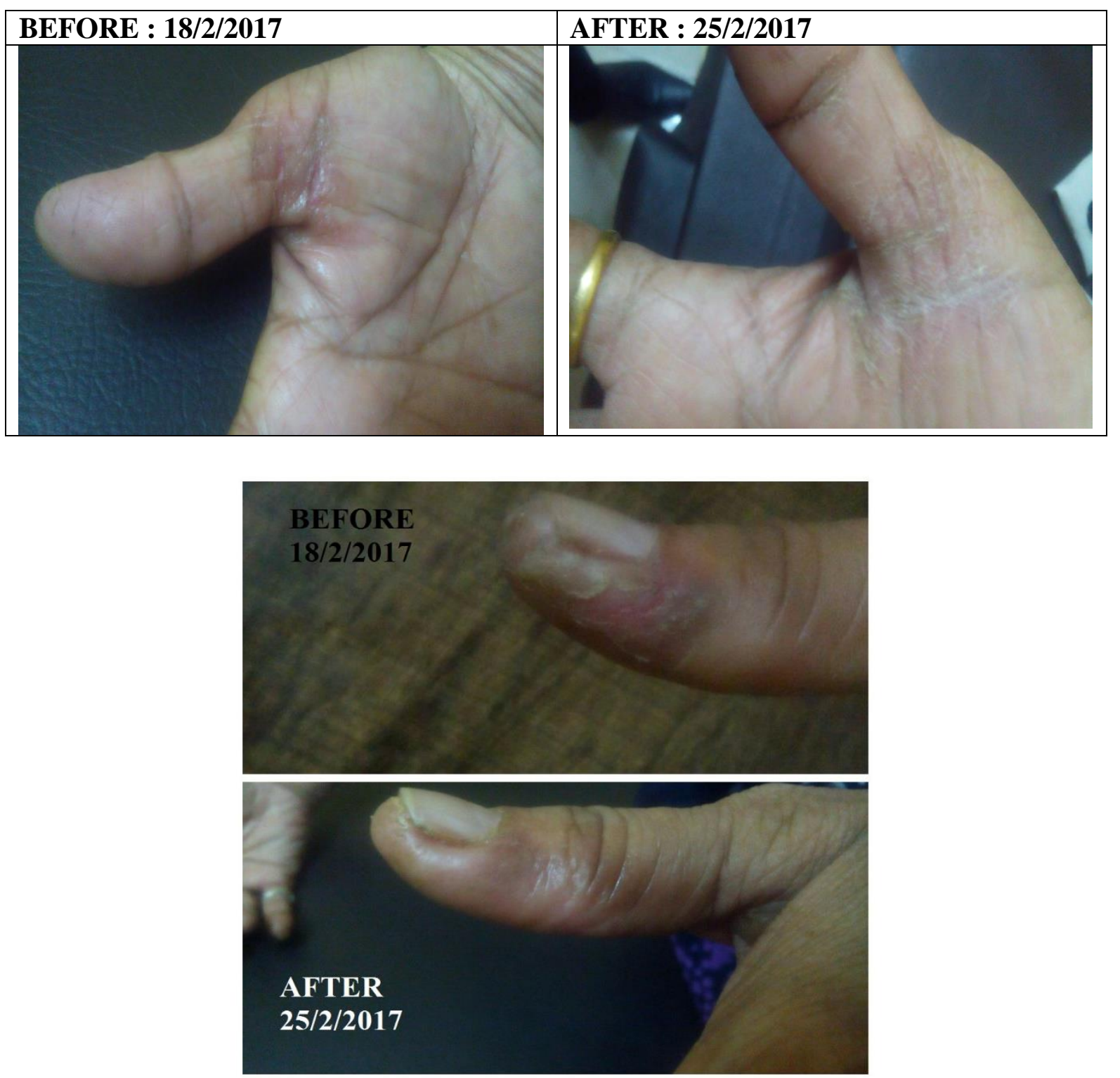

\section{Conclusion}

Since the therapy for vatakafaj kushta (CAD) has limitation in other pathies, Ayurvedic management can be effective therapy.

\section{References}

[1] Dr.Ganesh Krushana garde, (12th Ed.), Sarthavagbhat, vagbhtakrytaashtangrudhaya and its Marathi translation, nidanstan; kushat-switra-krumiadhya; chapter 14. Verse no.1 ; pune: profesent publishing house, 2009 ; page no.233.

[2] Dr.Brahmanand tripathied, 1sted, Charak samhita, volume 1, Nidan sthana, Adhya.no 5, verse no.1-3, pub by Chaukhamba Surabharati prakashan, reprinted 2009, page no.623.

[3] Skin diseases \& sexually Trasmitted infection, dr.uday khopkar, ( $5^{\text {th }}$ edi), balani publication, eczema, chapter no.9, page no.99. 
[4] Brhamananda Tripathi, ( $1^{\text {st }}$ Ed.). Charak samhita, Maharshi Charak. Nidanstan; Kushtanidanadhyaya: chapter 5. Verse no.6.Varanasi: Chukhambha prakashan, 2011; page no.625.

[5] Irritant contact dermatitis by Medscape, www.emedicine.medscape.com/article/1049353overview (updated on 26th sep 2016 \& downloaded on 27th feb 2017)

[6] Juss,s.s., indian med Gaz 1997, chapter-13,page no.194-196

[7] Nadkarni, A.K. popular press Ltd,Mumbai, 1976,3rd edition, Page no.1308-1315

[8] Methata,B.K., shitut., wankhade, H., Fitoterapia 1999,64,371-372

[9] Naik, G-H., Priyadarshini, K.I, R.G., Mishra, B., Mishra.K.P., Banavalikar, M.M.,Hari mohan, phytother Res2005, chapter-19,page no.582-586

[10] Gandharva haritaki (https://www.bimbima.com/ayurved/gandhavra-haritaki-churna-benifitsingredients-dosage/466/) : uploade on 2 september 2014 \& downloaded on 28 feb 2017.

[11] The ayurvedic pharmacopoeia of india-part-1, gov.of india ministry of health \& family welfare dep.of AYUSH.new delhi; vol-2, pg.no-84.

[12] The ayurvedic pharmacopoeia of india-part-1, gov.of india ministry of health \& family welfare dep.of AYUSH.new delhi; vol-2, pg.no-136.

[13] Brhamananda Tripathi, (1st Ed.).Charak samhita, Maharshi Charak. Chikitsa-stan;kushta chikitsa adhya: chapter 7. Verse no.99.Varanasi: Chukhambha prakashan, 2011; page no.320.

*Corresponding author.

E-mail address: dj85015@gmail.com/ yermeshilpa@gmail.com/smitazambare1@ gmail.com 